Original Article

\title{
Potential Hepatoprotective Effect of Cheatomorpha gracilis extract against High Fat Diet (HFD)-Induced Liver Damage, and its characterization by HPLC
}

\author{
Efeito Hepatoprotetor Potencial do Extrato de Cheatomorpha gracilis contra Dano \\ Hepático Induzido por Dieta Alta em Gordura (HFD), e sua caracterização por HPLC
}

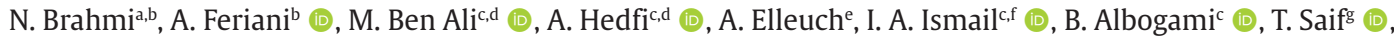 \\ H. Talarmin ${ }^{\mathrm{h}}$, A. El Feki ${ }^{\mathrm{b}}$ (D) and M. S. Allagui ${ }^{\mathrm{a}, \mathrm{b} *}$ (D) \\ a University of Sfax, Faculty of Sciences of Sfax, Laboratory of Animal Physiology, Sfax, Tunisia \\ ${ }^{\mathrm{b}}$ University of Gafsa, Faculty of Sciences of Gafsa, Research Unit of Macromolecular Biochemistry and Genetic, Gafsa, Tunisia \\ ${ }^{c}$ Department of Biology, College of Sciences, Taif University, P.O. Box 11099, Taif 21944, Saudi Arabia \\ dUniversity of Carthage, Faculty of Sciences of Bizerte, Laboratory of Environment Biomonitoring LR01 ES14, Zarzouna 7021, Tunisia \\ ${ }^{\mathrm{e}} \mathrm{CHU}$ Habib Bourguiba, Laboratory of Biochemistry, Sfax, Tunisia \\ ${ }_{\mathrm{f}}^{\mathrm{f}}$ Department of Plant Genetic Transformation, Agricultural Genetic Engineering Research Institute, Agricultural Research Center, 12619, Giza, Egypt \\ ${ }^{g}$ National Institute of Oceanography and Fisheries, Cairo, Egypt \\ ${ }^{\mathrm{h}}$ Université de Bretagne Occidentale, Laboratory ORPHY EA4324, UFR Sciences et Technique, Brest, France
}

\begin{abstract}
The current investigation was carried out to estimate the protective effect of aqueous extract of Cheatomorpha gracilis (AEC) against High fat Diet (HFD) induced liver damage in mice. The results of the in vitro study showed that AEC have higher antioxidant capacities in the DPPH and hydroxyl radical-scavenging assays. Indeed, many phenolic compounds (gallic acid, quercetin, naringenin, apigenin, kaempferol and rutin) were identified in the AEC. In the animal studies, during 6 weeks, HFD promoted oxidative stress with a rise level of malonaldehyde (MDA), protein carbonyls (PCOs) levels and a significant decrease of the antioxidant enzyme activities such as superoxide dismutase, catalase and glutathione peroxidase. Interestingly, the treatment with AEC ( $250 \mathrm{mg} / \mathrm{kg}$ body weight) significantly reduced the effects of HFD disorders on some plasmatic liver biomarkers (AST, ALT and ALP) in addition to, plasmatic proteins inflammatory biomarkers ( $\alpha_{2}$ and $\beta_{1}$ decreases, $\beta_{2}$ and $\gamma$ globulins increases). It can be suggest that supplementation of MECG displays high potential to quench free radicals and attenuates high fat diet promoted liver oxidative stress and related disturbances.
\end{abstract}

Keywords: C.gracilis aqueous extract, High Fed Diet (HFD), oxidative stress, phytochemistry analysis, hepatoprotective effects.

\begin{abstract}
Resumo
A presente investigação foi realizada para estimar o efeito protetor do extrato aquoso de Cheatomorpha gracilis (AEC) contra o dano hepático induzido por dieta rica em gordura (HFD) em camundongos. Os resultados do estudo in vitro mostraram que os AEC têm maiores capacidades antioxidantes nos ensaios DPPH e de eliminação de radicais hidroxila. De fato, muitos compostos fenólicos (ácido gálico, quercetina, naringenina, apigenina, kaempferol e rutina) foram identificados no AEC. Nos estudos em animais, durante 6 semanas, HFD promoveu estresse oxidativo com aumento do nível de malonaldeído (MDA), níveis de proteína carbonil (PCOs) e diminuição significativa das atividades de enzimas antioxidantes como superóxido dismutase, catalase e glutationa peroxidase. Curiosamente, o tratamento com AEC (250 mg / kg de peso corporal) reduziu significativamente os efeitos dos distúrbios de HFD em alguns biomarcadores hepáticos plasmáticos (AST, ALT e ALP), além de biomarcadores inflamatórios de proteínas plasmáticas (reduções $\alpha 2$ e $\beta 1$ / $\beta 2$ e $\gamma$ aumenta as globulinas). Pode-se sugerir que a suplementação de MECG apresenta alto potencial para extinguir os radicais livres e atenua o estresse oxidativo do fígado promovido pela dieta rica em gordura e distúrbios relacionados.
\end{abstract}

Palavras-chave: extrato aquoso de C.gracilis, dieta rica em nutrientes (HFD), estresse oxidativo, análise fitoquímica, efeitos hepatoprotetores.

*e-mail: amsallagui@yahoo.fr; amsallagui2018@gmail.com

Received: December 30, 2020 - Accepted: February 17, 2021 


\section{Introduction}

In today's modern lifestyle, a rise in dietary fat intake, important changes in our food habits and a decline in physical action represented by rise to an augmentation of metabolic disturbance including hypercholesterolemia and may lead health problems such as diabetes mellitus, steatosis and atherosclerosis (Steinberg, 2005; Hassan et al., 2011). Dyslipidemia, including high level of serum TC (total cholesterol), small density in lipoprotein cholesterol and a high level density lipoprotein cholesterol (HDL-ch), is a large scale risk cause for serious health diseases, namely, cardiovascular diseases, hypercholesterolemia and chronic liver diseases (Steinberg, 2005; Zou et al., 2006). Fat accumulation predisposes the liver to hypertrophy and secondary stresses such as oxidative stress (Musso et al., 2009). Consequently, structures of lipids are regarded as the substrate of lipid peroxidation consequent to exposure to oxygen species generated by poor scavenging and/ or depressed antioxidant enzymes (Videla et al., 2004). Undoubtly, oxidative stress could be considered cause or effect of liver disease. In fact, it is a reaction that happen when reactive oxygen species submerge the antioxidant defense. Free radicals such as superoxide-anion $\left(\mathrm{O}_{2}^{-{ }^{-}}\right)$, hydrogen-peroxide $\left(\mathrm{H}_{2} \mathrm{O}_{2}\right)$, and hydroxyl-radical $\left(\mathrm{OH}^{\circ}\right)$ which are produced in the human-body can be a decisive incidence in many physiological disorders, and may deteriorate the biological molecules and functional damage of the cells (Arbos et al., 2008). Redox modifications can be considered as a negative influence on endogenous antioxidant activities like enzymatic defense activity such catalase (CAT); superoxide dismutase (SOD) and glutathione peroxidase (GPx) or non-enzymatic component levels (Rjeibi et al., 2016). Nevertheless, endogenous defenses are not always sufficient to counteract free radicals' disturbances. Hence, the understanding of oxidative stress triggered by hypercholesterolemia turns into a considerable area of concentrate in the scientific community (Holvoet et al., 2004). Numerous therapeutic factors are ready for the management of hypercholesterolemia patients, and they are utilized to promote effective treatment (Hassan et al., 201). During the past few years, algae have attracted many researcher's attention because many studies have demonstrated that seaweeds are potential sources of valuable antioxidants. Not only do they exhibit various biological activities and therapeutic properties, but also have various beneficial effects on reducing plasma lipid. Indeed, seaweeds decrease white adipose tissue weight gain in obese mice fed with a high-fat diet (Maeda et al., 2009). In this study, green filamentous alga $C$. gracilis was chosen due to their abundance in a marine protected area in the Southern coast of Tunisia 'Hchechina'. Thus, the present investigation aimed to evaluate the antioxidant activities of $C$.gracilis aqueous extract (AEC) and to identify their phenolic compounds by HPLC analysis. Additionally, the possible efficiency of AEC against biochemical disturbances and hepatic oxidative stress damage in adult mice fed with high cholesterol diet were also determined.

\section{Material and Methods}

\subsection{Alga Material}

\subsubsection{Experimental procedure and Extraction of alga material}

C. gracilis was collected from Sfax coast, Tunisia, in April 2016. This macroalga was authenticated at Botany department, Faculty of Science Sfax, Tunisia. After collection, $C$. gracilis filaments were thoroughly washed and then shade dried. The dried samples were crushed in an electric mill till and a powder was obtained. The green alga powder was mixed with a measured quantity of distilled water and extracted using microwave at room temperature for special time. Then, the mixture was stirred at regular intervals to ensure homogenous exposure of the mixture to microwave irradiation. After extraction, the mixture was cooled at room temperature and centrifuged at $3250 \times \mathrm{g}$ for $10 \mathrm{~min}$. Micro-porous membranes $(0.45 \mu \mathrm{m})$ was used to collect the alga extracts. Finally, the rotary evaporation method was used to reduce the extract volume at room temperature $\left(45-55^{\circ} \mathrm{C}\right)$. The extraction yields were defined as the $\%$ of the initial powder of freeze-dried powder) and expressed by this Equation 1

$$
\text { Yield }(\%)=\frac{\text { Mass of powder after extraction }}{\text { Mass of the initial powder }} \times 100
$$

The resulting extracts were kept until use at $+4{ }^{\circ} \mathrm{C}$.

\subsubsection{Determination of protein and carotenoid content}

The amount of protein from green alga was measured according to the method of Bradford (1976), using bovine serum albumin as standard. The absorbance was measured at $595 \mathrm{~nm}$ and the values were expressed in $\mathrm{mg}$ per $\mathrm{g}$ of dry plant material., Carotenoid content was determined according to the method of Lichtenthaler (1987). The results were expressed in $\mathrm{mg} / \mathrm{g}$ dry plant material.,

\subsubsection{Identification of phenolic compounds}

According to the method of Singleton and Rossi (1965), AEC phenolic level was determined.

The flavonoid content in the aqueous extract was determined using a colorimetric method described by Ordonez et al. (2006). All determinations were performed in triplicate.

\subsubsection{HPLC analysis conditions}

For the determination of Cheatomorpha gracilis aqueous composition by high performance liquid chromatography (HPLC) analysis, C-18reversed-phase column (Zobrax, $250 \times 4.6 \mathrm{~mm}$ ) was used.

The mobile phase consists of acetonitrile water (98:2 v/v) as solvent A and glacial acetic and water $(58: 2 \mathrm{v} / \mathrm{v})$ as solvent $\mathrm{B}$. The flow rate was set at $0.9 \mathrm{ml} / \mathrm{min}$ and an amount of $20 \mu \mathrm{l}$ of extract was injected. The phenolic acids and flavonoids compounds were found at $280 \mathrm{~nm}$ and 360nm, respectively. 


\subsubsection{Evaluation of total antioxidant capacity (TAC)}

The total antioxidant capacities (TAC) were evaluated using the method of Prieto et al. (1999). The ascorbic acid was used as a reference standard and the antioxidant activity of the samples was expressed as milligrams of gallic acid equivalents per $\mathrm{ml}$.

\subsubsection{Determination of DPPH and hydroxyl radicals scavenging potential}

C.gracilis extracts antiradical effect was determined in terms of hydrogen-donating or radical-scavenging ability using DPPH radical according to the method of Son and Lewis (2002). The antioxidant activity of the corresponding extracts was measured using the stable free radical DPPH as a reagent (Son and Lewis, 2002). Besides, the used standard was the butylated hydroxytoluene BHT $(\mathrm{mg} / \mathrm{ml})$.

Using Fenton's reaction method, described by Li et al. (2008), the hydroxyl radical-scavenging assay was carried out.

\subsection{In vivo investigation}

2.2.1. Experimental design, the normal mice were divided into four groups of 8 mice each as follows:

Control: normal animals received distilled water and standard diet.

HFD: animals received $2 \%$ cholesterol and $0.2 \%$ cholic acid

to persuade hypercholesterolemia for 6 weeks.

HFD+ AEC: animals co-treated with high fat diet and AEC

(250mg/Kg body weight) by gavage for 6 weeks.

HFD: normal mice given AEC (250mg/Kg body weight).

\subsubsection{Analysis of plasma lipid and liver biomarkers}

Plasma lipid parameters such as total cholesterol (TCh), triacylglycerol (TG), LDLcholesterol (LDL-Ch) and high-density lipoprotein-cholesterol (HDL-C) levels were determined by were measured by autoanalyzer (Erba xl 200, Mannheim, Germany) using Erba diagnostic kit. Plasma AST, ALT and ALP activities were determinate in the chemistry laboratory of Sfax hospital by commercial kits from (Biolabo, France)

\subsubsection{Plasmatic inflammatory proteins}

The plasma inflammatory proteins (albumin, $\alpha 2$, $\beta 1, \beta 2$ and $\gamma$ globulins) were determined with capillary ${ }^{\circledR}$ electrophoresis using commercial kit Capillarys Sebia.

\subsubsection{Evaluation of liver lipid peroxidation}

Lipid peroxidation level was measured by the quantification of thiobarbituric acid-reactive substances (TBARS) according to the method of Fraga et al. (1988).

\subsubsection{Evaluation of liver protein peroxidation}

Protein carbonyls (PCOs) content in liver was measured using the method of Reznick and Packer (1994). The absorbance was noted at $370 \mathrm{~nm}$.

\subsubsection{Estimation of liver antioxidant enzyme activities}

Liver tissue homogenate was used for the assay of endogenous antioxidant enzymes catalase (CAT), superoxide dismutase (SOD) and glutathione peroxidase (GPX) activities, which were assessed respectively by the method of Aebi (1984), Kakkar et al. (1984) and Rotruck et al. (1973).

\subsubsection{Analysis of histological examination}

For histological studies, some liver tissues were placed in $10 \%$ of buffered formalin solution for 48 hours and then processed using graded ethanol. The sections were embedded in paraffin, serially sectioned at a thickness of $5 \mu \mathrm{m}$ and stained with hematoxylin and eosin for light microscopic observation.

\subsection{Statistics}

The data of each parameter are expressed as means \pm standard deviation (SD). The determinations were realized from eight animals per group, and differences were calculated by a one-way analysis of variance (ANOVA) followed by the Fisher test (Stat View).

\section{Results}

\subsection{C. gracilis characterization}

\subsubsection{Total protein and carotenoid content}

The obtained results demonstrated that C.gracilis was rich in protein (Table 1 ) with a significant percentage relative to the overall weight (48.15\%), and rich in carotenoid $(23.77 \pm 3.2 \mathrm{mg}$ per gram dry plant material).

\subsubsection{Extraction yield}

For the macroalga species utilizing different solvents, the extraction yields, defined as a \% of initial powder of freeze-dried powder, were tabulated in Table 2. Our data shown that yield extraction was varied between $0.96 \%$ and $13.44 \%$ depending on the extraction solvent with the following order: water $>$ ethanol-water $(70 v-30 v)>$ methanol $>$ ethyl acetate $>$ ethanol $>$ dichloromethane.

\subsubsection{Phenolic compounds contents}

The total phenolic and flavonoid content of different solvent extracts of $C$.gracilis extracts were determined and

Table 1. Total carotenoid and Protein content of $C$. gracilis.

\begin{tabular}{ccc}
\hline Alga & Protein $(\mathbf{m g} / \mathbf{g}$ dry plant material) & Total carotenoid (mg/g dry plant material) \\
\hline Chaetomorpha gracilis & $48.15 \pm 1.23$ & $23.77 \pm 3.82$ \\
\hline
\end{tabular}

Values are mean \pm S.D of three experimental tests. 
the results are presented in Table 2 . The highest phenolic and flavonoid content was recorded in water extract estimated to $96.7 \pm 0.7 \mathrm{mg}$ of gallic acid per gram of dry residue and $71.62 \pm 9.54 \mathrm{mg}$ of quercetin per gram of dry residue, respectively.

\subsubsection{Identification of phenolic compounds in C. gracils extract}

In this investigation, the HPLC analysis was used to determine AEC phenolic compounds (Figure 1). Table 3 shows the area and concentration of C.gracilis identified compounds, which include gallic acid (Concentration $151.06 \mu \mathrm{g} / \mathrm{mL}$ extract; Area $1.11 \%$ ), quercetin(Concentration

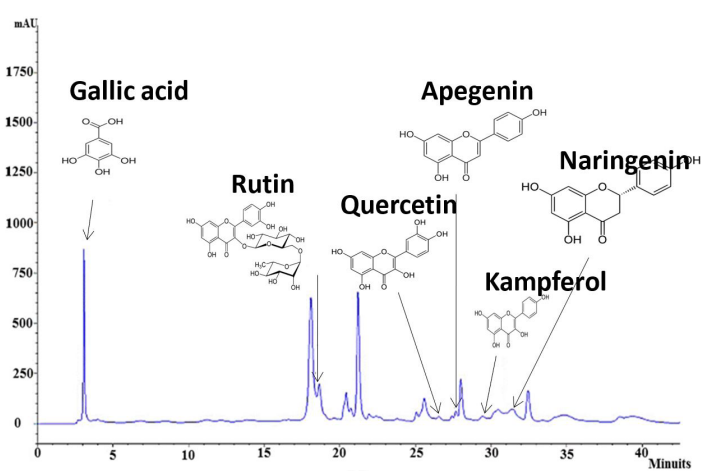

Figure 1. Phenolic compounds of Cheatomorpha gracilis extract by chemical High Performance Liquid Chromatography (HPLC) analysis (gallic acid, Rutin, quercetin, Apegenin, kaempferol and Naringenin).
$450.30 \mu \mathrm{g} / \mathrm{mL}$ extract; Area $1.00 \%$ ), naringenin (Concentration $77.38 \mu \mathrm{g} / \mathrm{mL}$ extract; Area 0.94\%), apigenin (Concentration $29.34 \mu \mathrm{g} / \mathrm{mL}$ extract; Area 0.32\%), kaempferol (Concentration $67.53 \mu \mathrm{g} / \mathrm{mL}$ extract; Area $0.53 \%$ ) and rutin (Concentration $80.31 \mu \mathrm{g} / \mathrm{mL}$ extract; Area $0.65 \%$ ).

\subsubsection{AEC antioxidant proprieties}

The total antioxidant activity of different solvent extracts of C.gracilis was shown in Figure 2. The highest antioxidant activity was observed in water extract $(18.7 \pm 1.54 \mathrm{mg}$ of gallic acid per g dry residue) as compared to all other solvent extracts.

\subsubsection{DPPH and Hydroxyl radical-scavenging activity of different seaweed extracts}

The free radical-scavenging activity of the different extracts was tested through DPPH-method and the results were compared with BHT in Table 1 and expressed in $\mathrm{IC}_{50}$ values (extract concentrations required to scavenge DPPH radical by $50 \%$ ). Thus, a lower $\mathrm{IC}_{50}$ value would reflect the antioxidant activity of the sample. The IC50 followed the order: dichloromethane extract > ethyl acetate extract > methanol extract $>$ Ethanol extract $>$ Ethanol/water extract $>$ water extract. Hence, the aqueous extract was considered as the best anti-radical power, which confirmed their high phenolic and flavonoid compounds. The determination of the concentration corresponding to $50 \%$ of the inhibition of radical hydroxyl showed that the IC50 of the water extract of C.gracilis was the lowest $(0.019 \mathrm{mg} / \mathrm{ml})$.

Table 2. Extract yield and chemical composition of different extracts of $C$. gracilis.

\begin{tabular}{|c|c|c|c|c|c|}
\hline Extracts & Yield (\%) & $\begin{array}{c}\text { Flavonoid } \\
\text { (mg QE/g DR) }\end{array}$ & $\begin{array}{c}\text { Phenolic } \\
\text { (mg GAE/g DR) }\end{array}$ & $\begin{array}{c}\text { DPPH IC50 } \\
\left(\mu \mathrm{g} \mathbf{m L}^{-1}\right)\end{array}$ & $\begin{array}{c}\text { OH·IC50 } \\
\left(\mu \mathrm{g} \mathbf{~ m L}^{-1}\right)\end{array}$ \\
\hline Methanol & $5.03 \pm 0.10$ & $33.81 \pm 1.68$ & $59.18 \pm 3.18$ & $0.135 \pm 0.007$ & $0.052 \pm 0.007$ \\
\hline Ethanol & $1.85 \pm 0.27$ & $54.93 \pm 0.968$ & $84.35 \pm 5.73$ & $0.093 \pm 0.002$ & $0.145 \pm 0.021$ \\
\hline Ethanol/water & $5.89 \pm 0.60$ & $19.62 \pm 4.24$ & $21.4 \pm 1.69$ & $0.061 \pm 0.004$ & $0.061 \pm 0.007$ \\
\hline Water & $13.44 \pm 0.65$ & $71.62 \pm 9.54$ & $96.7 \pm 0.7$ & $0.038 \pm 0.007$ & $0.019 \pm 0.001$ \\
\hline Ethyl-acetate & $2.46 \pm 0.54$ & $11.43 \pm 2.02$ & $23.6 \pm 4.8$ & $0.87 \pm 0.01$ & $0.36 \pm 0.08$ \\
\hline Dichloromethane & $0.96 \pm 0.09$ & $5.03 \pm 0.10$ & $13.83 \pm 1.09$ & $1.13 \pm 0.09$ & $1.16 \pm 0.05$ \\
\hline Vitamin c & - & - & - & - & $0.4 \pm 0.02$ \\
\hline BHT & - & - & - & $0.162 \pm 0.001$ & - \\
\hline
\end{tabular}

Values are mean \pm SD of three experimental tests; $\mathrm{mg}$ QE/g DR: mg of quercetin, $\mathrm{mg}$ GAE/g DR: mg gallic acid equivalents per g dry residue; equivalent per gram dry residue; $\mathrm{OH}^{\bullet}$ : Hydroxyl radical-scavenging activity; DPPH: DPPH radical-scavenging activity.

Table 3. Phenolic compounds of AEC by HPLC analysis.

\begin{tabular}{cccc}
\hline Compound & Retention time $(\mathbf{m i n})$ & Content $(\mu$ g compound/g extract) & Area $(\%)$ \\
\hline Gallic Acid & 3.07 & $151.06 \pm 11$ & 1.11 \\
Apigenin & 27.34 & $450.30 \pm 28.1$ & 1.00 \\
Naringenin & 31.56 & $77.38 \pm 4.2$ & 0.94 \\
Quercetin & 26.54 & $29.34 \pm 1.3$ & 0.32 \\
kaempferol & 29.40 & 67.53 & 0.53 \\
Rutin & 18.17 & $80.31 \pm 6.21$ & 0.65 \\
\hline
\end{tabular}




\subsection{In vivo study}

\subsubsection{Body, absolute liver and adipose weights}

Table 4 presents the body, liver, and adipose weights in all treated groups of mice after 6 weeks of the experimentation. The final body weights were increased in all groups. However, the higher body gain was observed in HFD group. The co-treatment with aqueous alga extract significantly retarded this body gain in HFD+AEC group. HFD remarkably elevated the weight of liver and adipose tissues. Nevertheless, a significant organs weight reduction was shown in HFD+ACE mice, as compared to HFD animals.

\subsubsection{Hepatic markers}

HFD induced a significant increase in AST, ALT and ALP activities by $42 \%, 23 \%$ and $53 \%$, respectively, compared with control (Table 5). Nevertheless, and compared to HFD- group, the co-treatment with AEC for 6 weeks improved ALT, AST and APL activities.

\subsubsection{Lipid profile}

The results observed after treatment with AEC on various lipid markers in the groups under study are given in Table 6. Hypercholesterolemia caused a significant increase in total cholesterol, triglycerides, LDL-Ch levels, while HDL-Ch level was decreased compared to controls untreated mice. Treatment with AEC $(250 \mathrm{mg} / \mathrm{kg}$ ) after the hypercholesterolemia induction protect the rise total cholesterol, triglycerides, LDL-Ch levels and reduce the drop of HDL-Ch compared to the HFD damaged mice.

\subsubsection{AEC and inflammation biomarkers}

Results presented in Figure 3 revealed a significant decrease in the plasma levels of $\alpha 2$ and $\beta 1$, by $28,44 \%$, with significant increase in albumin, $\beta 2$ and $\gamma$ globulins rates by $39 \% 43$ and $44 \%$, respectively, in HFD treated mice compared
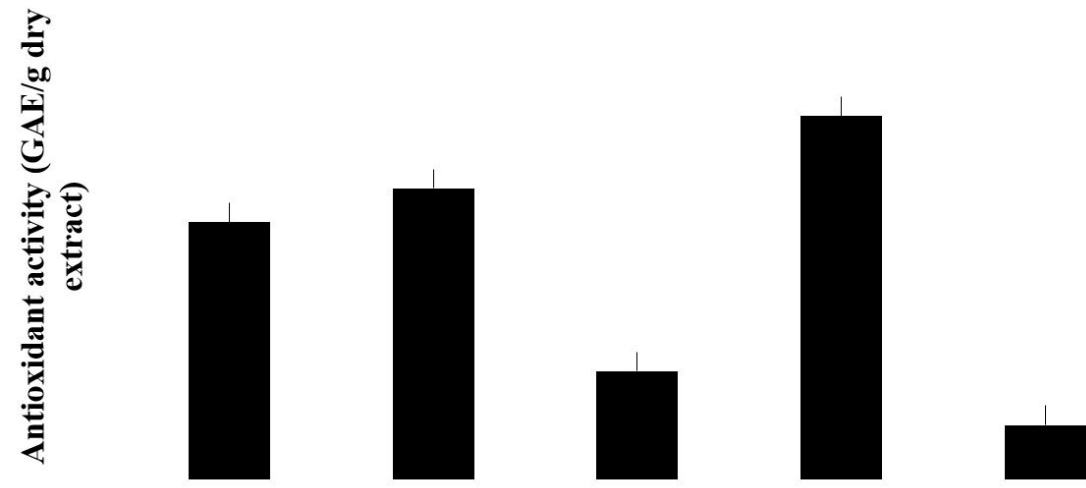

Figure 2. Antioxidant activity of different extracts of $C$. gracilis. Values are mean \pm SD of three experimental tests, mg GAE/g DR: mg gallic acid equivalents per $\mathrm{g}$ dry residue.

Table 4. Effect of AEC on body weight, liver and adipose tissues relative weight of control and treated mice groups.

\begin{tabular}{ccccc}
\hline & Controls & HFD & HFD+AEC & AEC \\
\hline Initial body weight $(\mathrm{g})$ & $33.2 \pm 1.24$ & $32.12 \pm 1$ & $32.12 \pm 3.33$ & $32.5 \pm 2.27$ \\
Final body weight $(\mathrm{g})$ & $35.77 \pm 2.4$ & $41.15 \pm 3.9$ & $35.74 \pm 0.65^{++}$ & $34.5 \pm 1.59$ \\
Body weight gain (\%) & $2.57 \pm 0.43$ & $9.03 \pm 0.3^{* *}$ & $3.62 \pm 0.2^{++}$ & $1.5 \pm 0.29$ \\
Relative liver weight (\%) & $4.68 \pm 0.35$ & $7.12 \pm 0.33^{*}$ & $5.85 \pm 0.03+$ & $4.98 \pm 0.18$ \\
Relative white adipose tissue weight (\%) & $4.96 \pm 0.27$ & $9.18 \pm 0.1^{* *}$ & $4.38 \pm 0.29^{++}$ & $4.73 \pm 0.25$ \\
\hline
\end{tabular}

Values are means for eight mice in each group. Relative liver weight: (liver weight)/body weight (BW)*100; Relative white adipose weight: (white adipose weight)/body weight $(\mathrm{BW}){ }^{*} 100$; HFD and treated groups vs control group: ${ }^{*} \mathrm{p}<0.05$; ${ }^{* *} \mathrm{p}<0.01$; HFD group vs (HFD+CAE) group: ++p $<0.01$.

Table 5. Effect in serum liver injury biomarkers of control and experimental groups of mice, after 6 weeks of treatment.

\begin{tabular}{ccccc}
\hline $\begin{array}{c}\text { Parameters and } \\
\text { treatments }\end{array}$ & Control & HDF & HDF+AEC & AEC \\
\hline AST (UI/I) & $691.5 \pm 24$ & $749 \pm 44.24^{*}$ & $708.5 \pm 53.03$ & $672 \pm 2.82$ \\
ALT (UI/I) & $26 \pm 8$ & $112.5 \pm 26.12^{* *}$ & $91 \pm 0.07^{*++}$ & $29 \pm 1$ \\
ALP (UI/I) & $74.5 \pm 7.77$ & $243 \pm 18.38^{* *}$ & $146 \pm 27.87^{*++}$ & $79.5 \pm 9.19$ \\
\hline
\end{tabular}

ALT, alanine aminotransferase; AST, aspartate aminotransferase; ALP, alkaline phosphatase. Values are means \pm SD for eight mice in each group. HFD and AEC-treated groups vs. control group: ${ }^{*} \mathrm{p}<0.05 ;{ }^{* *} \mathrm{p}<0.01 ;$ HFD + AEC group vs. HFD group: $+\mathrm{p}<0.05 ;++\mathrm{p}<0.01$ 
to untreated animals. In fact, the increase of albumin, $\beta 2$ and $\gamma$ globulins levels and decreases in the plasma levels of $\alpha 2$ and $\beta 1$ as a result of hypercholesterolemia administration were largely protected in the AEC+HFD group.

\subsubsection{Estimation of lipid peroxidation (TBARS) and protein carbonyl (PCO) levels in liver}

The obtained results revealed disturbances in TBARS levels and protein carbonyls (PCO) products in liver tissues.
The TBARS and PCO levels exposed a significant increase in the HFD-exposed mice when compared with those of controls (Figure 4). These damages were significantly alleviated by AEC $(250 \mathrm{mg} / \mathrm{kg})$ administration.

\subsubsection{Antioxidant defenses in mouse liver}

The hepatic antioxidant enzymes activities (GPx, catalase, and SOD) of all treated mice were presented in Table 7. Antioxidant enzymes activities decreased

Table 6. Lipid profile of control or treated mice with HFD, AEC and their combination.

\begin{tabular}{cccc}
\hline Parameters and treatments & Control & HDF & HDF+AEC \\
\hline TC $(\mathrm{mmol} / \mathrm{L})$ & $3.7 \pm 0.74$ & $6.44 \pm 0.37^{* *}$ & $5.37 \pm 1.23^{*+}$ \\
TG $(\mathrm{mmol} / \mathrm{L})$ & $1.19 \pm 0.13$ & $2.14 \pm 0.26^{* *}$ & $1.91 \pm 0.12^{++}$ \\
HDL-ch $(\mathrm{mmol} / \mathrm{L})$ & $2.32 \pm 0.55$ & $1.32 \pm 0.98^{* *}$ & $1.73 \pm 0.30$ \\
LDL-ch $(\mathrm{mmol} / \mathrm{L})$ & $0.88 \pm 0.04$ & $1.82 \pm 0.29^{* *}$ & $1.65 \pm 0.7$ \\
\hline
\end{tabular}

TC, Total cholesterol;TG, Triglycerides; HDL-ch, High-density lipoproteins of cholesterol; LDL-ch, Low density lipoproteins of cholesterol. Values are means \pm SD for eight mice in each group. HFD and AEC-treated groups vs. control group: ${ }^{*} p<0.05 ;{ }^{* *} p<0.01 ;$ HFD + AEC group vs. HFD group: $+\mathrm{p}<0.05 ;++\mathrm{p}<0.01$.

$\square$ Control $\square$ HFD $\square$ HFD+AEC $\square$ AEC
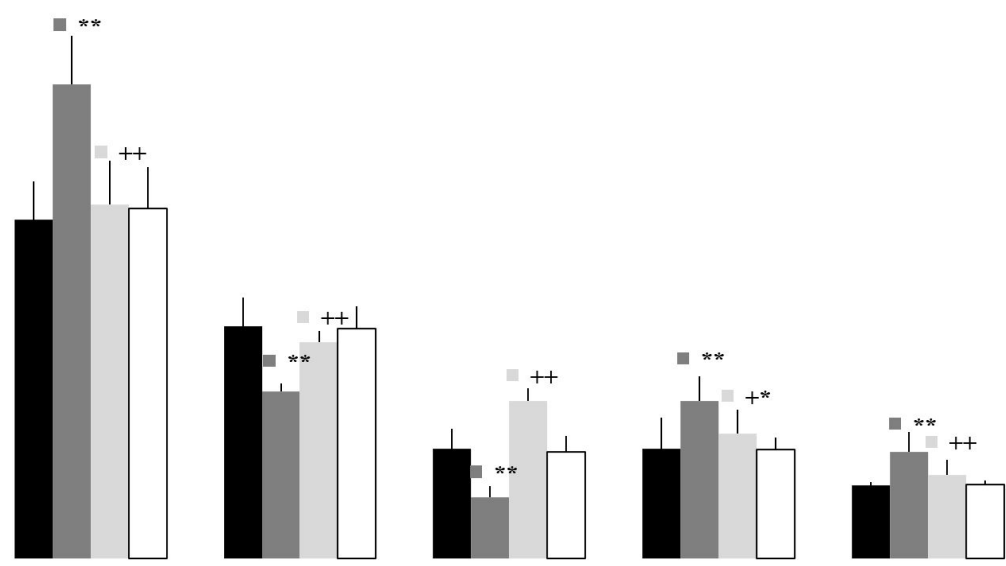

Figure 3. Effect of ACE supplementation on plasma levels of inflammatory proteins. Data are given as mean \pm SD for group of eight mice each. Values are statistically presented as follows: HFD and AEC-treated groups vs. control group: ${ }^{*} \mathrm{p}<0.05 ;{ }^{* *} \mathrm{p}<0.01$. HFD + AEC group vs. HFD group: $+p<0.05 ;++p<0.01$.
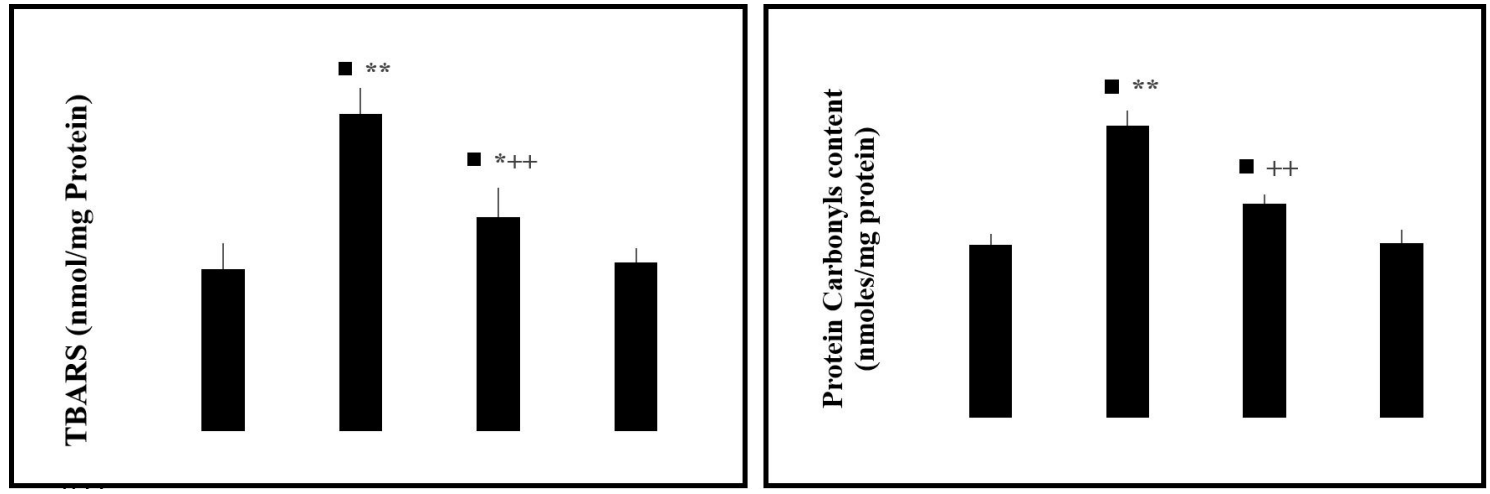

Figure 4. Effects of C.gracilis aqueous extract (AEC) on TBARS and protein carbonyls products (PCO) in HFD-treated mice. TBARS: thiobarbituric acid reactive substance. Data are presented as mean $\pm \mathrm{SD}, \mathrm{n}=8 .{ }^{*} \mathrm{P} \leq 0.05,{ }^{* *} \mathrm{P} \leq 0.01$ compared with the control group. $+\mathrm{P}$ $\leq 0.05,++\mathrm{P} \leq 0.01$ as compared with HFD- treated mice. 
significantly, (SOD, 68\%), (CAT, 67\%) and (GPx, 78\%) following HFD exposition, when compared to control group. Interestingly, the co-administration of AEC with HFD considerably diminished these enzymatic antioxidant activities as compared to the HFD group, which recovered normal values.

\subsubsection{Histological studies}

The histology assessment with the hematoxylin and eosin staining of liver tissue of all groups was collected and represented in Figure 5. The histological sections of the hepatic cells the control mice or treated with aqueous extract of C.gracilis (AEC) $(250 \mathrm{mg} / \mathrm{kg}$ ) alone showing normal liver architecture (Figure 5A and B). In the HFD group, the hepatic tissue showed an increase of fat accumulation (steatosis) (Figure5C). Conversely, in HFD-fed mice supplemented with the aqueous extract of $C$.gracilis (AEC) (Figure 5D) lipid accumulation in liver was reduced and liver tissues and hepatic architecture were restored.

Lipid content observed in the paraffin sections of mice liver stained with oil red 0 method (Figure 6 ). In the hepatic tissues of HFD mice, an abnormal level of lipid revealed by a large number of red-colored fine granules distributed throughout the cytoplasm of the hepatocytes when compared to the control group (Figure 6A). A quantity of $250 \mathrm{mg} / \mathrm{kg}$ AEC administration for 6 weeks decreased the lipid accumulation approximately 56\% compared with HFD model group (Figures 6B).

\section{Discussion}

Hypercholesterolemia is an increasingly serious global health problem, not only for the damage it causes in its own right, but also due to the attributed health threats, especially coronary heart disease (Haslam and James, 2005). Moreover, dyslipidemia was considered as one of the factors responsible for chronic liver diseases (Castelli, 1986; Soltis et al., 2017). Pharmacological therapy for dyslipidemia causing chronic liver diseases is not approved at the present time. Thus, in the current research, a purpose was made to know the principal biochemical, and histological changes in mice submitted to High Fed Diet

Table 7. GPX, SOD and CAT in liver of adult mice: Control and treated with HFD, HFD+ACE or ACE.

\begin{tabular}{ccccc}
\hline $\begin{array}{c}\text { Parameters and } \\
\text { treatments }\end{array}$ & Control & HDF & HDF+AEC & AEC \\
\hline GPX & $6.37 \pm 0.39$ & $1.43 \pm 0.3^{* *}$ & $4.24 \pm 0.94^{*++}$ & $6.95 \pm 0.58$ \\
SOD & $9.05 \pm 1.53$ & $2.94 \pm 0.95^{* *}$ & $8.24 \pm 0.69++$ & $8.69 \pm 2.3$ \\
CAT & $2.72 \pm 0.57$ & $0.89 \pm 0.44^{* *}$ & $1.4 \pm 0.17++$ & $2.7 \pm 0.21$ \\
\hline
\end{tabular}

Values are means \pm SD for eight mice in each group. HFD and AEC-treated groups vs. control group: ${ }^{*} \mathrm{p}<0.05 ;{ }^{* *} \mathrm{p}<0.01 ; \mathrm{HFD}+\mathrm{AEC}$ group vs. HFD group: $+\mathrm{p}<0.05 ;++\mathrm{p}<0.01$; CAT: $\mu$ moles $\mathrm{H}_{2} \mathrm{O}_{2}$ degraded/min/mg protein; SOD: units/mg protein; $\mathrm{GP}_{\mathrm{x}}$ : nmoles of GSHoxidized/min/mg protein.
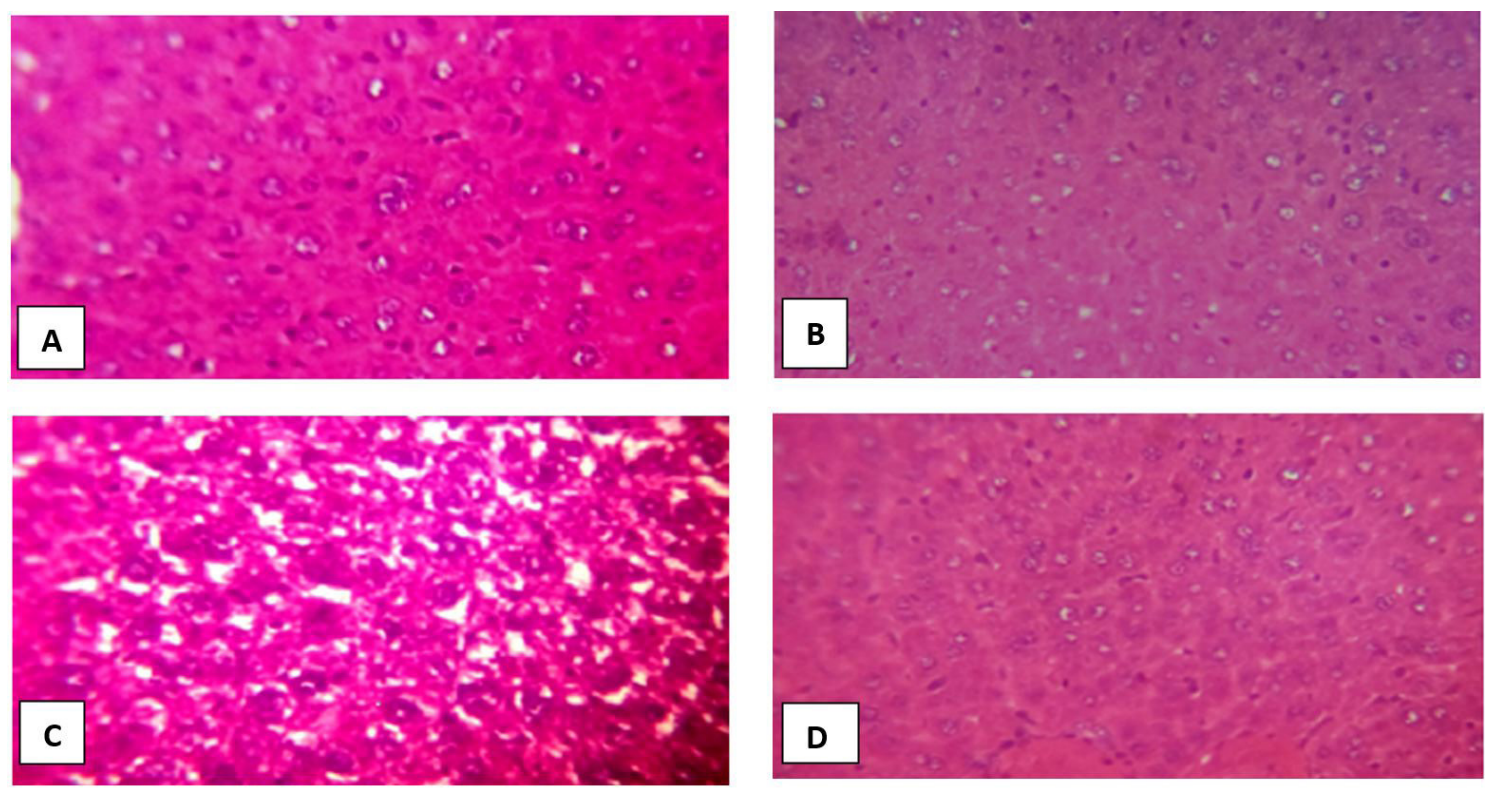

Figure 5. Photographs of liver tissues in control and experimental treated mice. Liver tissue sections stained with hematoxylin and eosin (original magnification $\times 400$ ). (A), in control mice showing normal histoarchitecture and radiating cell arrangement. (B) In mice treated with aqueous extract of C.gracilis (AEC) $(250 \mathrm{mg} / \mathrm{kg}$ ) alone showing the normal liver structure. (C) In High fed diet (HFD) mice, representative photograph shows a significant lipid accumulation. (D) In group co-treated with HFD and AEC, was observed the reduction of fat accumulation. 
(HFD). Besides, the protective effect of aqueous extract of green Alga C.gracilis (AEC) was explored.

The findings presented in this study revealed that the diet enriched with $2 \%$ of cholesterol supplied during
6 weeks in mice was accompanied by a gain of body weight and adipose tissue and liver weight increases. Upon that syndrome, it could be hypothesized that diet enriched with cholesterol may induce obesity in mice (Srivastava

$\mathbf{A}$
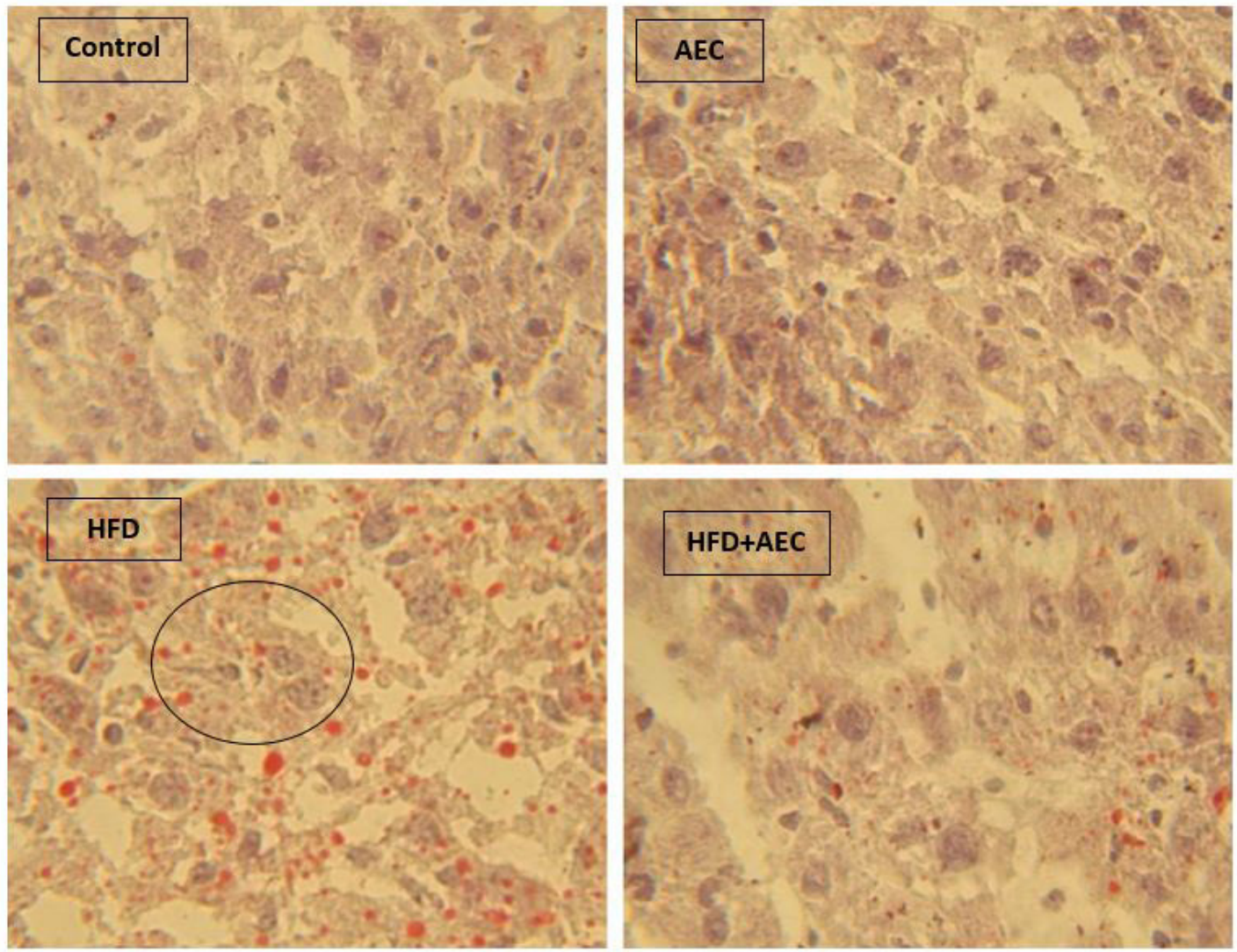

B

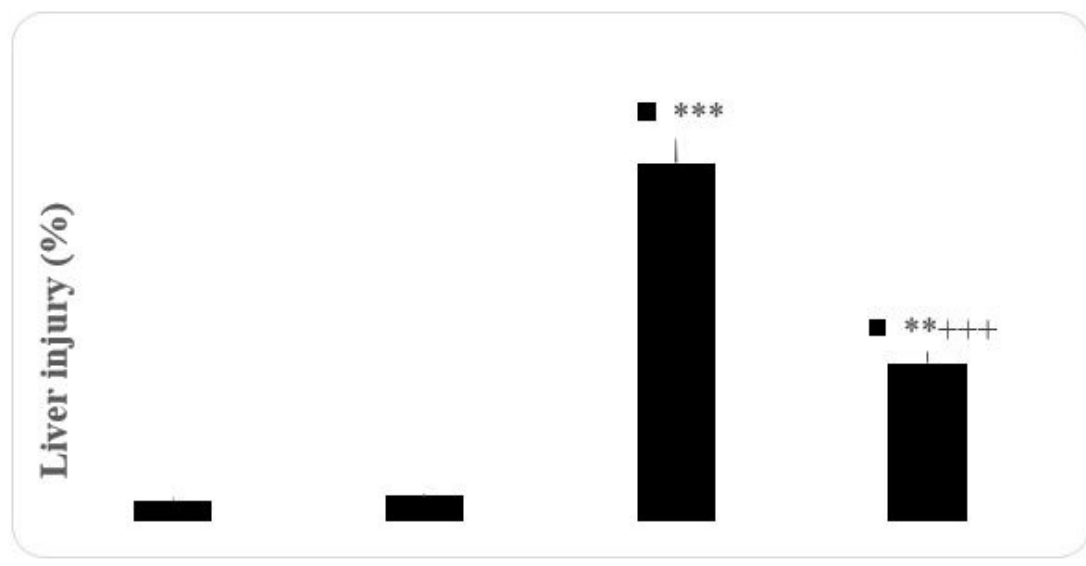

Figure 6. Photomicrographs of hepatocytes in control and experimental treated mice. Liver tissue sections stained with oil red $\mathrm{O}(\times 200)$ (A) and scored (B) by the semi-quantitative percentage of damaged area. (Control) control mice and (AEC) treated with C. gracilis extract $(250 \mathrm{mg} / \mathrm{kg}$ ) alone, showed normal structure. (HFD) high fed diet treated mice, showed a significant increase of lipid content; (AEC + HFD) co-treated with high fed diet and alga extract $(250 \mathrm{mg} / \mathrm{kg}$ ), representative micrograph revealed significantly reduced lipid liver content. Values are expressed as the mean $\pm \mathrm{SD} .{ }^{* *} \mathrm{p}<0.01 ;{ }^{* * *} \mathrm{p}<0.001$, indicates a significant difference compared to the control group. $++\mathrm{p}<0.01$, indicates a significant difference compared to the HFD alone group. 
and Shivanandappa, 2010; Wu et al., 2010). Interestingly, the supplementation of AEC tended to reduce body weight, adipose tissue weight gain and liver weight. The antilipase activity of AEC may also be associated with its obesity-preventing property by increasing excretion and evacuating fecal matter (Carriere et al., 1998). The effect of $C$. gracilis extract in decreasing body weight may be due to the synergistic action of its compounds (protein, Flavonoids and phenolic compounds). In addition, the beneficial activities of AEC associated to the powerful effect of $\beta$-carotene, flavonoids, which promote satiety and affect gastric emptying and gastric hormone secretion. Indeed, carotenoid is a powerful antioxidant that serves as a pre-hormone, since through metabolism, it is converted into retinoic acid, which functions as a ligand, regulating the expression of genes involved in metabolic processes (Mounien et al., 2019).

It is worthy to note that lipids play an important role in chronic liver disease incidence (Duan et al., 2017). The data presented in this research confirmed that the administration of high fat diet provoked the change of lipid parameters with a rise level of triglyceride, total Cholesterol, and LDL-Ch levels and decrease in HDL-Ch level. These changes are the pertinent markers of the hypercholesterolemia and the risk of hepatic diseases (Monika and Geetha, 2015). The co-treatment with AEC $(250 \mathrm{mg} / \mathrm{Kg}$ ) significantly reduced the elevated levels of total cholesterol, triglycerides, LDL-Ch and increased of HDL-Ch level as compared to HFD group.

It has been described that extracts that are rich in flavonoids prevent dyslipidemia associated to high fat diet and chronic liver diseases by means of its modulatory effect on hepatic gene expression associated with lipid metabolism (Sudhop et al., 2002). In this regard, the findings reported by Kolsi et al. (2017) indicated that the reduction in cholesterol and TG levels could be associated with the decrease of its anabolism, which mainly involves HMG-CoA (3-hydroxy-3-methylglutaryl-CoA) and acylCoA (cholesterol acyltransferase), and with the inhibition of its absorption. Similar studies could be carried out in the treatment with algae compound, reinforcing the fact that the consumption of seaweeds as a diet supplement prevents hypercholesterolemia (Young et al., 2004). Indeed, AEC supplementation did not only reduce the TC, TG and LDL-ch, but also increased the HDL-ch, which is known to play a crucial role in the transport of cholesterol and in its involvement in preventing the oxidation of LDL-Ch (Libby et al., 2000). AEC has anti-obesity, antioxidant and anti-inflammatory activities (Chen and Li, 2007; Ben Ali et al., 2015). Several studies demonstrated that phenolic compounds are responsible for hypolipidemic activities (Cheong et al., 2010; Zhang et al., 2015). Liver biomarker enzymes including transaminases (AST and ALT) and alkaline phosphatase (ALP) are indicators of liver dysfunction and hepatic injury. Thus, the increase of hepatic parameters has been shown to be a strong risk factor for chronic liver diseases in many populations (Saoudi and El Feki, 2012; Tlili et al., 2016). Our findings shown that the administration of HFD induced a severe liver injury as manifested by a significant rise in the activities of ALT, AST and ALP in mice plasma. These increases are associated to the structural alteration integrity of liver cell membranes, as they are cytoplasmic in location and released into the blood stream after hepatocellular necrosis (Zhou et al., 2010). Hepatic dysfunction is commonly accompanied by chronic inflammation, and the persistence of this inflammation is attributed to hepatocyte necrosis and/or apoptosis processes (Friedman, 2008; Lee and Friedman, 2011). These forms of liver cell injury can activate inflammatory cells and immune response. Accordingly, results presented in this research revealed a decrease in the plasma levels of $\alpha 2$ and $\beta 1$, with significant increase in albumin, $\beta 2$ and $\gamma$ globulins rates in HFD treated mice compared to untreated animals. In fact, the increase of albumin, $\beta 2$ and $\gamma$ globulins levels and decreases in the plasma levels of $\alpha 2$ and $\beta 1$ as a result of hypercholesterolemia administration were largely protected in the AEC+HFD group. The data presented in the current work are in accordance with a previous investigation by Ncibi et al. (2008), which has demonstrated that plasmatic transaminases activities are important biomarkers for liver damage and have been used as a biomarker of steatosis and as a non-alcoholic fatty liver predictor of liver disease progression (Ncibi et al., 2008).

Moreover, hypercholesterolemia in HFD-treated mice could be the cause of the alterations of liver parenchymal cells that induced the disorders of hepatic serum marker enzymes. In the same context, several studies have also reported that the disturbances of liver enzyme secretion, lipid parameters changes and fat accumulation are hazardous factors that contribute to the development of hepatosteatosis and facilitate the non-alcoholic fatty liver incidences (Adams et al., 2005; Singal et al., 2011). It is noteworthy to mention that the supplementation of AEC was proven to alleviate the elevation of plasma AST, ALT and ALP activities caused by HFD administration in experimental animals. AEC was found to protect the plasma membrane from damage and the reduction of the toxicity caused by HFD. Our data are evidenced by histological examination in liver sections. The liver of HFD-mice revealed an increase of lipid accumulation (steatosis) associated with a major liver structure damage and disruption of hepatocytes arrangement. The cytoprotective effect of AEC has been proven by the decrease of fat accumulation in liver cotreated mice.

Apart from abnormalities in lipid metabolism and hepatic biomarker enzymes, another important aspect of NAFLD is the presence of oxidative stress (Singal et al., 2011). Indeed, hepatic cells are the main tissues that are involved in lipid metabolism, and thus vulnerable to potential oxidative damage in the condition of hyperlipidemia (Vernon et al., 2011).

It is reported that free radicals induce cells damage through mechanisms involving covalent binding to macromolecules such as proteins oxidation and lipid peroxidation with subsequent dysfunction cytosolic and membranous cellular mechanisms, especially liver injury (Poli 1993; Renaud et al., 2014). Our data demonstrated that HFD causes a markedly increase in the content of lipid peroxidation and protein carbonyls products in the liver of HFD-treated mice, which confirms the pro/antioxidant disorders in hepatic cells. Accumulating TBARS level in the lipid bilayer membrane of liver can cause the loss 
of its integrity and the liberation of hepatic enzymes into circulation, confirming that ROS have been involved in the pathogenesis of various types of liver diseases (Li et al., 2015). Regarding the antioxidants enzymes, our results showed that a high fat diet caused the impairment of the SOD and GPx and catalase activities in mice liver. The antioxidant enzymatic activities inhibition may be due to the accumulation of high reactive free radicals, leading to deleterious effects such as the inactivation of their function mechanisms (Li et al., 2015). Our data are in agreement with several studies, reporting that ROS generated by hypercholesterolemia reduced the activities of antioxidant enzymes and provoked imbalances between antioxidant defenses and ROS-mediated disturbances (Umamaheswari and Chatterjee, 2008). The supplementation of AEC was able to decrease the oxidative stress. Indeed, the AEC treatment significantly reduced lipid peroxidation and protein oxidation in liver. This protective effect by the green alga extract against oxidative stress could be explained by the presence of polyphenols, flavonoids, carotenoids and proteins in the AEC. Furthermore, the positive effect of AEC was mediated by the inhibition of the key enzymes of obesity, such as lipase inhibitory activity, and by its richness in macro- and micro-elements $(\mathrm{Mg}, \mathrm{Ca}, \mathrm{Na}, \mathrm{K}$, Fe and $\mathrm{Zn}$ ) (works in progress). These are the cofactors of the metalloenzymes, which have a crucial role in regulating the status pro/antioxidant (Brahmi et al., 2018). Thus, minerals elements deficiency predisposes to an exaggerated response to immune stress and free radicals generation. Hence, in our study, the defence offered by the alga against hypercholesterolemia could be attributed to the presence of the above-mentioned antioxidants (Zhang et al., 2003; Ying-Ying et al., 2015). Upasani and Balaraman (2003) have also noticed an increase in the antioxidant status of the mice by the administration of the alga Porphyra haitanesis fraction.

\section{Conclusion}

The findings obtained in this work noticeably shown that AEC is able to prevent the dyslipidemia damages in mice fed with high fat diet for 6 weeks. It also diminished the oxidant status by decline lipid peroxidation and the protein oxidation and enhancing the antioxidants activities in the liver tissues. Our results indicate that AEC supplementation of diet during 45 days was great to decrease inflammatory markers, provides the biochemical parameters and enhancing the morphology hepatocytes impairment. Overall, our study confirmed that the beneficial effect of the extract was due to its strong antioxidant potentials.

\section{Acknowledgements}

This work was supported by the Tunisian Ministry of the High Education and Scientific Research. The authors extend their appreciation to Taif University for funding current work by Taif University Researchers Supporting Project number (TURSP-2020/120), Taif University, Taif, Saudi Arabia.

\section{References}

ADAMS, L.A., ANGULO, P. and LINDOR, K.D., 2005. Nonalcoholic fatty liver disease. Canadian Medical Association Journal, vol. 172, no. 7, pp. 899-905. http://dx.doi.org/10.1503/cmaj.045232. PMid:15795412.

AEBI, H., 1984. Catalase in vitro. Methods in Enzymology, vol. 105, pp. 121-126. http://dx.doi.org/10.1016/S0076-6879(84)050163. PMid:6727660.

ARBOS, K., CLARO, L., BORGES, L., SANTOS, C. and WEFFORT-SANTOS, A., 2008. Human erythrocytes as a system for evaluating the antioxidant capacity of vegetable extracts. Nutrition Research, vol. 28, no. 7, pp. 457-463. http://dx.doi.org/10.1016/j. nutres.2008.04.004. PMid:19083446.

BEN ALI, M., GUESMI, F., HARRATH, A.H., ALWASEL, S., HEDFI, A., NCIB, S., LANDOULSI, A., ALDAHMASH, B., and BEN-ATTIA, M., 2015. Investigation of Antiulcer and Antioxidant Activity of Juniperus phoenicea L. (1753) Essential Oil in an Experimental Rat Model. Biological and Pharmaceutical Bulletin, vol. 38, no. 11, pp. 1738-1746. https://doi.org/10.1248/bpb.b15-00412. PMid: 26521824

BRADFORD, M.M., 1976. A rapid and sensitive method for the quantitation of microgram quantities of protein utilizing the principle of protein-dye binding. Analytical Biochemistry, vol. 72, no. 1-2, pp. 248-254. http://dx.doi.org/10.1016/00032697(76)90527-3. PMid:942051.

BRAHMI, N., SAOUDI, M., KADRI, Y., KALLEL, C., EL EUCH, A., MAKNI-AYADI, F. , HARRATH, A., and ALLAGUI, M.S., 2018. Protective effect of Chaetomorpha gracilis aqueous extract against erythrocytes oxidative damage induced by high fat diet in treated mice. Archives of Physiology and Biochemistry, vol. 125, no. 3, pp. 220-227. https://doi.org/ 10.1080 /13813455.2018. 1448997. PMid: 29544357

CARRIERE, F., WITHERS-MARTINEZ, C., VAN TILBEURGH, H., ROUSSEL, A., CAMBILLAU, C. and VERGER, R., 1998. Structural basis for the substrate selectivity of pancreatic lipases and some related proteins. Biochimica et Biophysica Acta (BBA)-. Reviews on Biomembranes, vol. 1376, no. 3, pp. 417-432. PMid:9805004.

CASTELLI, W., 1986. The triglyceride issue: A view from Framingham. American Heart Journal, vol. 112, no. 2, pp. 432-437. http:// dx.doi.org/10.1016/0002-8703(86)90296-6. PMid:3739899.

CHEN, J. and LI, X., 2007. Hypolipidemic effect of flavonoids from mulberry leaves in triton WR-1339 induced hyperlipidemic mice. Asia Pacific Journal of Clinical Nutrition, vol. 16, suppl. 1, pp. 290-294. PMid:17392121.

CHEONG, S., KIM, M., SOK, D., HWANG, S., KIM, J., KIM, H., LEE, J.H., KIM, Y.B. and KIM, M.R., 2010. Spirulina prevents atherosclerosis by reducing hypercholesterolemia in rabbits fed a high-cholesterol diet. Journal of Nutritional Science and Vitaminology, vol.56, no. 1, pp. 34-40. http://dx.doi.org/10.3177/ jnsv.56.34. PMid:20354344.

DUAN, X., QIANG, M., CGANGYUAN, W., ZHIHAO, L., HUIJUM, S. and XIAOKUI, H., 2017. Effects of calycosin against high fat diet-induced nonalcoholic fatty liver disease in mice. Journal of Gastroenterology and Hepatology, vol. 102, pp. 188-202. PMid:28699662.

FRAGA, C.G., MOTCHNIK, P.A., SHIGENAGA, M.K., HELBOCK, H.J., JACOB, R.A. and AMES, B.N., 1988. Lipid peroxidation measured as thiobarbituric acid-reactive substances in tissue slices: characterization and comparison with homogenates and microsomes. Free Radical Biology \& Medicine, vol. 4, no. 3, pp. 55-161. http://dx.doi.org/10.1016/0891-5849(88)90023-8. PMid:3356355. 
FRIEDMAN, S.L., 2008. Mechanisms of hepatic fibrogenesis. Gastroenterology, vol. 134, no. 6, pp. 1655-1669. http://dx.doi. org/10.1053/j.gastro.2008.03.003. PMid:18471545.

HASLAM, D. and JAMES, W., 2005. Obesity. Lancet, vol. 366, no. 9492, pp. 1197-1209. http://dx.doi.org/10.1016/S0140-6736(05)674831. PMid:16198769.

HASSAN, S., EL-TWAB, S.A., HETTA, M. and MAHMOUD, B., 2011. Improvement of lipid profile and antioxidant of hypercholesterolemic albino rats by polysaccharides extracted from the green alga Ulva lactuca Linnaeus. Saudi Journal of Biological Sciences, vol. 18, no. 4, pp. 333-340. http://dx.doi. org/10.1016/j.sjbs.2011.01.005. PMid:23961145.

HOLVOET, P., KRITCHEVSKY, S., TRACY, R., MERTENS, A., RUBIN, S., BUTLER, J., GOODPASTER, B. and HARRIS, T.B., 2004. The metabolic syndrome, circulating oxidized LDL, and risk of myocardial infarction in well-functioning elderly people in the health, aging, and body composition cohort. Diabetes, vol. 53, no. 4, pp. 1068-1073. http://dx.doi.org/10.2337/diabetes.53.4.1068. PMid:15047623.

RJEIBI, I., BEN SAAD, A. and HFAIEDH, N., 2016. Oxidative damage and hepatotoxicity associated with deltamethrin in rats: the protective effects of Amaranthus spinosus seed extract. Biomedicine and Pharmacotherapy, vol. 84, pp. 853-860. http:// dx.doi.org/10.1016/j.biopha.2016.10.010. PMid:27728895.

KAKKAR, P., DAS, B. and VISWANATHAN, P.N., 1984. A modified spectrophotometric assay of superoxide dismutase. Indian Journal of Biochemistry \& Biophysics, vol. 21, no. 2, pp. 130-132. PMid:6490072.

KOLSI, R.B.A., JARDAK, N., HAJKACEM, F., CHAABEN, R., JRIBI, I., FEKI, A.E., REBAI, T., JAMOUSSI, K., FKI, L., BELGHITH, H. and BELGHITH, K., 2017. Anti-obesity effect and protection of liver-kidney functions by Codium fragile sulphated polysaccharide on high fat diet induced obese rats. International Journal of Biological Macromolecules, vol. 102, pp. 119-129. http://dx.doi.org/10.1016/j.ijbiomac.2017.04.017. PMid:28392390.

LEE, U.E. and FRIEDMAN, S.L., 2011. Mechanisms of hepatic fibrogenesis. Best Practice \& Research. Clinical Gastroenterology, vol. 25, no. 2, pp. 195-206. http://dx.doi.org/10.1016/j. bpg.2011.02.005. PMid:21497738.

LI, N., XIA, T. and NEL, A.E., 2008. The role of oxidative stress in ambient particulate matter-induced lung diseases and its implications in the toxicity of engineered nanoparticles. Free Radical Biology E' Medicine, vol. 4, no. 9, pp. 1689-1699. http://dx.doi.org/10.1016/j.freeradbiomed.2008.01.028. PMid:18313407.

LI, S., TAN, H.Y., WANG, N., ZHANG, Z.J., LAO, L., WONG, C. and FENG, Y., 2015. The role of oxidative stress and antioxidants in liver diseases. International Journal of Molecular Sciences, vol. 16, no. 11, pp. 26087-26124. http://dx.doi.org/10.3390/ ijms161125942. PMid:26540040.

LIBBY, P., AIKAWA, M. and SCHONBECK, U., 2000. Cholesterol and atherosclerosis. Biochimica et Biophysica Acta, vol. 1529, no. 1-3, pp. 99-309. PMid:11111097.

LICHTENTHALER, H., 1987. Chlorophylls and carotenoids: pigments of photosynthetic biomembranes. Methods in Enzymology, vol. 148, pp. 350-382. http://dx.doi.org/10.1016/00766879(87)48036-1.

MAEDA, H., HOSOKAWA, M., SASHIMA, T., MURAKAMI-FUNAYAMA, K. and MIYASHITA, K., 2009. Anti-obesity and anti-diabetic effects of fucoxanthin on diet-induced obesity conditions in a murinemodel. Molecular Medicine Reports, vol. 2, no.
6, pp. 897-902. http://dx.doi.org/10.3892/mmr_00000189. PMid:21475918.

SAOUDI, M. and EL FEKI, A., 2012. Protective Role of Ficus carica Stem Extract against Hepatic Oxidative Damage Induced by Methanol in Male Wistar Rats. Evidence-based Complementary and Alternative Medicinevol, vol. 8, pp. 150-458.

MONIKA, P. and GEETHA, A., 2015. The modulating effect of persea americana fruit extract on the level of expression of fatty acid synthase complex, lipoprotein lipase, fibroblast growth factor-21 and leptin-A biochemical study in rats subjected to experimental hyperlipidemia and obesity. Phytomedicine, vol. 22, no. 10, pp. 939-945. http://dx.doi.org/10.1016/j. phymed.2015.07.001. PMid:26321743.

MOUNIEN, L., TOURINIAIRE, F. and LANDRIER, J., 2019. Anti-Obesity effect of carotenoids: direct impact on adipose tissue and adipose tissue-driven indirect effects. Nutrients, vol. 11, no. 7, pp. 1562. http://dx.doi.org/10.3390/nu11071562. PMid:31373317.

MUSSO, G., GAMBINO, R. and CASSADER, M., 2009. Recent insights into hepatic lipid metabolism. Progress in Lipid Research, vol. 48, no. 1, pp. 1-26. http://dx.doi.org/10.1016/j.plipres.2008.08.001. PMid:18824034.

NCIBI, S., BEN OTHMAN, M., AKACHA, A., KRIFI, M.N. and ZOURGUI, L., 2008. Opuntia ficus indica extract protects against chlorpyrifos-induced damage on mice liver. Food and Chemical Toxicology, vol. 46, no. 2, pp. 797-802. http://dx.doi. org/10.1016/j.fct.2007.08.047. PMid:17980473.

ORDONEZ, A., GOMEZ, J., VATTUONE, M. and ISLA, M., 2006. Antioxidant activities of Sechium edule swart extracts. Food Chemistry, vol.97, no. 3, pp. 452-458. http://dx.doi.org/10.1016/j. foodchem.2005.05.024.

POLI, G., 1993. Liver damage due to free radicals. British Medical Bulletin, vol. 49, no. 3, pp. 604-620. http://dx.doi.org/10.1093/ oxfordjournals.bmb.a072634. PMid:8221026.

PRIETO, P., PINEDA, M. and AGUILAR, M., 1999. Spectrophotometric quantitation of antioxidant capacity through the formation of a phosphomolybdenum complex: specific application to the determination of vitamin E. Analytical Biochemistry, vol. 269, no. 2, pp. 337-341. http://dx.doi.org/10.1006/abio.1999.4019. PMid:10222007.

RENAUD, H.J., CUI, J.Y., LU, H. and KLAASSEN, C.D., 2014. Effect of diet on expression of genes involved in lipid metabolism, oxidative stress, and inflammation in mouse liver-insights into mechanisms of hepatic steatosis. PLoS One, vol. 14, no. 2, pp. 9-88. http://dx.doi.org/10.1371/journal.,pone.0088584. PMid:24551121.

REZNICK, A. and PACKER, L., 1994. Oxidative damage to proteins: spectrophotometric method for carbonyl. Methods in Enzymology, vol. 233, pp. 357-363. http://dx.doi.org/10.1016/ S0076-6879(94)33041-7. PMid:8015470.

ROTRUCK, J.T., POPE, A.L., GANTHER, H.E., SWANSON, A.B., HAFEMAN, D.G. and HOEKSTRA, W.G., 1973. Selenium: biochemical role as a component of glutathione peroxidase. Science, vol. 179, no. 4073, pp. 588-590. http://dx.doi.org/10.1126/science.179.4073.588. PMid:4686466.

SINGAL, A.K., JAMPANA, S.C. and WEINMAN, S.A., 2011. Antioxidants as therapeutic agents for liver disease. Liver International, vol. 31, no. 10, pp. 1432-1448. http://dx.doi.org/10.1111/j.14783231.2011.02604.x. PMid:22093324.

SINGLETON, V.L. and ROSSI, J.A., 1965. Colorimetry of total phenolics with phosphomolybdic phosphotungstic acid reagents. American Journal of Enology and Viticulture, vol. 16, pp. 144-158. 
SOLTIS, A.R., KENNEDY, N.J., XIN, X., ZHOU, F., FICARRO, S.B., YAP, Y.S., MATTHEWS, B.J., LAUFFENBURGER, D.A., WHITE, F.M., MARTO, J.A., DAVIS, R.J. and FRAENKEL, E., 2017. Hepatic dysfunction caused by consumption of a high-fat diet. Cell Reports, vol. 21, no. 11, pp. 3317-3328. http://dx.doi.org/10.1016/j.celrep.2017.11.059. PMid:29241556.

SON, S. and LEWIS, B., 2002. Free radical scavenging and antioxidant activity of caffeic acid amide and ester analogues: structureactivity relationship. Journal of Agricultural and Food Chemistry, vol. 50, no. 3, pp. 468-472. http://dx.doi.org/10.1021/jf010830b. PMid:11804514.

SRIVASTAVA, A. and SHIVANANDAPPA, T., 2010. Hepatoprotective effect of the root extract of Decalepis hamiltonii against carbon tetrachloride-induced oxidative stress in rats. Food Chemistry, vol. 118, no. 2, pp. 411-417. http://dx.doi.org/10.1016/j. foodchem.2009.05.014.

STEINBERG, D., 2005. Thematic review series: the pathogenesis of atherosclerosis: an interpretive history of the cholesterol controversy, part III: mechanistically defining the role of hyperlipidemia. Journal of Lipid Research, vol. 46, no. 10, pp. 2037-2051. http://dx.doi.org/10.1194/jlr.R500010-JLR200. PMid:15995167.

SUDHOP, T.D., LUTJOHANN, A., KODAL, M., IGEL, D.L., TRIBBLE, S., SHAH, I., PEREVOZSKAYA, I. and VON BERGMANN, K., 2002. Inhibition on intestinal cholesterol absorption by ezetimibe in humans. Circulation, vol. 106, no. 15, pp. 1943-1948. http://dx.doi. org/10.1161/01.CIR.0000034044.95911.DC. PMid:12370217.

TLILI, N., FERIANI, A., ALLAGUI, M.S., SAADOUI, E., KHALDI, A. and NASRI, N., 2016. Effects of Rhus tripartitum fruit extract on CCl4induced hepatotoxicity and cisplatin-induced nephrotoxicity in rats. Canadian Journal of Physiology and Pharmacology, vol. 94, no. 8, pp. 801-807. http://dx.doi.org/10.1139/cjpp-20160029. PMid:27351070.

UMAMAHESWARI, M. and CHATTERJEE, T., 2008. In vitro antioxidant activities of the fractions of Coccinnia grandis $\mathrm{L}$. leaf extract. African Journal of Traditional., Complementary and Alternative, vol. 5, pp. 61-73.

UPASANI, C. and BALARAMAN, R., 2003. Protective effect of Spirulina on lead induced deleterious changes in the lipid peroxidation and endogenous antioxidants in rats. Phytotherapy Research, vol. 17, no. 4, pp. 330-334. http://dx.doi.org/10.1002/ptr.1135. PMid:12722134.

VERNON, G., BARANOVA, A. and YOUNOSSI, Z.M., 2011. Systematic review: the epidemiology and natural history of non-alcoholic fatty liver disease and non-alcoholic steatohepatitis in adults. Alimentary Pharmacology \& Therapeutics, vol. 34, no. 3, pp. 274-285. http://dx.doi.org/10.1111/j.1365-2036.2011.04724.x. PMid:21623852.

VIDELA, L., RODRIGO, R., ORELLANA, M., FERNANDEZ, V., TAPIA, G., QUINONES, L., VARELA, N., CONTRERAS, J., LAZARTE, R., CSENDES, A., ROJAS, J., MALUENDA, F., BURDILES, P., DIAZ, J.C., SMOK, G., THIELEMANN, L. and PONIACHIK, J., 2004. Oxidative stress-related parameters in the liver of non-alcoholic fatty liver disease patients. Clinical Science, vol. 106, no. 3, pp. 261268. http://dx.doi.org/10.1042/CS20030285. PMid:14556645.

WU, C.H., YANG, M.Y., CHAN, K.C., CHUNG, P.J., OU, T.T. and WANG, C.J., 2010. Improvement in high-fat diet-induced obesity and body fat accumulation by a Nelumbo nucifera leaf flavonoid-rich extract in mice. Journal of Agricultural and Food Chemistry, vol. 58, no. 11, pp. 7075-7081. http://dx.doi.org/10.1021/jf101415v. PMid:20481471.

YING-YING, S., HUI, W., GAN-LIN, G., YIN-FANG, P., BIN-LUN, Y. and CHANG-HAI, W., 2015. Green alga Ulva pertusa a new source of bioactive compounds with antialgal activity. Environmental Science and Pollution Research International, vol. 22, no. 13, pp. 10351-10359. http://dx.doi.org/10.1007/s11356-015-4244-x. PMid:25724801.

YOUNG, C.E., KARAS, R.H. and KUVIN, J.T., 2004. High-density lipoprotein cholesterol and coronary heart disease. Cardiology in Review, vol. 12, no. 2, pp. 107-119. PMid:14766026.

ZHANG, Q., LI, N., ZHOU, G., LU, X., XU, Z. and LI, Z., 2003. In vivo antioxidant activity of polysaccharide fraction from Porphyra haitanesis (Rhodephyta) in aging mice. Pharmacological Research, vol. 48, no. 2, pp. 151-155. http://dx.doi.org/10.1016/S10436618(03)00103-8. PMid:12798667.

ZHANG, Y., MUSTAPHA, U.I., MAZNAH, I., NORSHARINA, I., AINI, I. and MAIZATON, A.A., 2015. High fat diet-induced inflammation and oxidative stress are attenuated by $\mathrm{N}$-acetylneuraminic acid in rats. Journal of Biomedical Science, vol. 2015, pp. 22-96. PMid:26498218.

ZHOU, D., RUAN, J., CAI, Y., XIONG, Z., FU, W. and WEI, A., 2010. Antioxidant and hepatoprotective activity of ethanol extract of Arachniodes exilis (Hance) Ching. Journal of Ethnopharmacology, vol. 129, no. 2, pp. 232-237. http://dx.doi.org/10.1016/j. jep.2010.03.016. PMid:20347029.

ZOU, Y., LI, J., LU, C., WANG, J., GE, J., HUANG, Y., ZHANG, L. and WANG, Y., 2006. High-fat emulsion-induced rat model of nonalcoholic steatohepatitis. Life Sciences, vol. 79, no. 11, pp. 1100-1107. http://dx.doi.org/10.1016/j.lfs.2006.03.021. PMid:16624332. 